\title{
Identifying and quantifying the threats to biodiversity in the $U$ Minh peat swamp forests of the Mekong Delta, Vietnam
}

\author{
RACHel NuWer and Diana Bell
}

\begin{abstract}
The landscape of $U$ Minh in southern Vietnam contains the country's last remaining fragments of peat swamp forest and is home to several globally threatened species. Despite the presence of two national parks, evidence indicates that illegal natural resource use by local communities has had a significant effect on species populations. We investigated the nature and extent of natural resource use in $\mathrm{U}$ Minh. Interviews revealed that location is a significant determining factor in whether or not individuals choose to harvest resources, suggesting that the national parks are having some positive results in curtailing illegal harvesting. Most hunting and fishing is carried out for trade purposes and most interviewees indicated a preference for consuming livestock, suggesting that resource users do not rely on wildlife for subsistence but rather for supplementing their income. People who prefer consuming wild meat were found to be more likely to harvest natural resources than people who prefer consuming livestock, demonstrating a potential link between these behavioural issues. The preference for wild meat decreases with increasing price, in contrast with urban consumers who value more expensive wild meat varieties, which suggests that different factors are driving wild meat consumption among the rural Vietnamese. The majority of interviewees perceived a decrease in species populations, attributing the decline primarily to harvesting pressures and thus indicating that strict regulation of illegal harvesting activities is necessary to protect U Minh's remaining biodiversity.
\end{abstract}

Keywords Fishing, hunting, pangolin, peat swamp, resource use, U Minh, Vietnam, wild meat

\section{Introduction}

Since the early 1990s hunting has become the major $\checkmark$ threat to tropical species because of a growing worldwide demand for wildlife products (Bennett et al., 2002). South-east Asia plays a significant role in the trade as both a supplier and consumer of wildlife goods (Bennett et al., 2002; World Bank, 2005; TRAFFIC, 2008).

RACHEL NUWER (Corresponding author) and DiANA BELL School of Biological Sciences, The University of East Anglia, Norwich, Norfolk, NR4 7TJ, UK. E-mail RachelNuwer@gmail.com

Received 10 December 2011. Revision requested 28 March 2012.

Accepted 6 June 2012. First published online 9 October 2013
The effects of this demand on the region's biodiversity could result in another example (Roberton, 2007) of the empty forest syndrome (Redford, 1992).

Vietnam is one of the most biologically diverse countries and plays a major role in international wildlife trade. A total of 512 species that have been assessed in Vietnam are currently categorized as threatened, including 54 mammals, 45 birds, 57 reptiles and amphibians and 73 fishes (IUCN, 2012). Regional declines of species in Vietnam have occurred during the past 20 years as hunting for subsistence has increasingly been replaced by hunting for trade (Donovan, 2004; Corlett, 2007; Roberton, 2007).

Although the sale, advertisement, storage and slaughter of wildlife without government permission and proof of registration are illegal, law enforcement is weak and corruption is common (Donovan, 2004; Corlett, 2007; Roberton, 2007; Newton et al., 2008; TRAFFIC, 2008; WCS, 2009). A framework of conservation laws exists in Vietnam but management and application of these laws is generally decentralized to local governments, which lack the capacity, staff and skills necessary for enforcement (World Bank, 2005).

An understanding of the ways in which humans interact with and potentially threaten species is needed to reverse species declines, including an understanding of hunters, traders and consumers, and their motives (Milner-Gulland \& Rowcliffe, 2007). Here we investigate how local people living in the U Minh landscape utilize and affect natural resources within the forest.

\section{Study area}

The landscape of $U$ Minh contains the remnants of what was once a vast peat swamp ecosystem, estimated to have covered 1.6 million ha in 1940, that has since been reduced to c. 60,000 ha and contains two national parks (CARE, 2004b). Melaleuca cajuputi dominates the area, varying from dense monoculture Melaleuca plantings to seminatural Melaleuca forests with high conservation value (Buckton et al., 1999).

U Minh Ha National Park in Ca Mau province and U Minh Thuong National Park in Kien Giang province include the largest patches of Melaleuca forest and contain what is thought to be the majority of the region's remaining biodiversity (CARE, 2004b,c). In addition to these protected areas, a matrix of forest and fishery enterprises 
with similar habitats to the national parks are situated between the parks (Bull et al., 2008). In 2012 U Minh Ha employed c. 42 rangers and U Minh Thuong employed c. 62 staff members. $\mathrm{U}$ Minh $\mathrm{Ha}$ is traversed by a number of roads, making it easy for rangers to patrol but also providing a possible means of access for natural resource users.

The national parks support some of the highest avian biodiversity in the Mekong Delta (Buckton et al., 1999; Torell et al., 2003; CARE, 2004a). Field surveys have also confirmed the existence of the hairy-nosed otter Lutra sumatrana, small-clawed otter Aonyx cinerea, fishing cat Prionailurus viverrinus, large-spotted civet Viverra megaspila and pangolin Manis javanicus within the parks (CARE, 2004a). Ten of the 32 mammal species occurring in the parks are nationally and/or globally threatened (Buckton et al., 1999; CARE, 2004a). As a result of habitat loss through fire, human encroachment and wildlife trade, species abundance has significantly declined over the past 30 years (CARE, 2004a, 2004b).

As a result of human settlement the buffer zones of the national parks contain almost no natural patches of Melaleuca forest but some areas are important foraging grounds for species of conservation concern such as otters, civets and birds (CARE, 2004a; Bull et al., 2008). Buffer zone residents are not permitted to enter the core zone of the national park and are prohibited from hunting in the buffer zone. However, anecdotal reports of illegal harvesting indicate that violations occur (Torell et al., 2003; CARE, 2004a).

\section{Methods}

This study was carried out during April-May 2010 in U Minh $\mathrm{Ha}$, the forest and fishery enterprises, and U Minh Thuong (Fig. 1). Ten hamlets within eight communes were selected for the survey, based on their vicinity to the national parks or forest and fishery enterprises and/or their reputation as areas where resource users lived.

The survey team comprised the researcher and a translator. Within each hamlet 20 households were randomly selected for interview, using systematic sampling of every two to three houses. The mean number of households per hamlet was 188 (range 82-286). The questionnaires included three sections: demographics, food security and natural resource use. Questions about resource use included whether an interviewee ever entered the forest, what they collected from the forest and whether they knew anyone else who went to the forest. Interviewees were also asked to describe the food they eat most often and the food they would prefer to eat if cost, availability and legal status were not issues. Interviews were semi-structured but open questioning was used when possible. Questions and answers were given in both Vietnamese and English, and all

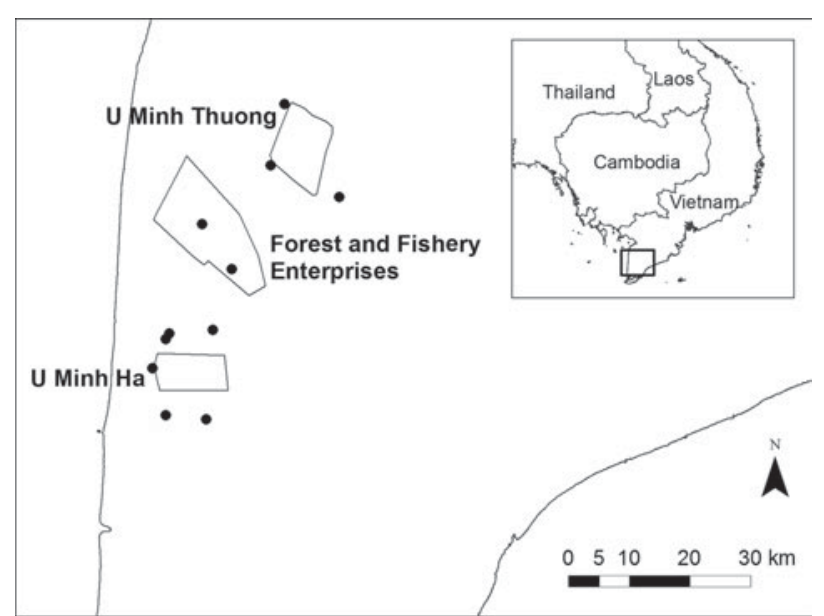

FIG. 1 Map of the study area in southern Vietnam, which comprised U Minh Ha and U Minh Thuong National Parks and forest and fishery enterprises. Circles represent hamlets where interviews were conducted. The rectangle on the inset shows the location of the main map in Vietnam.

responses were written down while the interview was taking place.

Responses to questions were often highly variable and some interviewees declined to answer certain questions. Response frequencies are presented as percentages in the format of $x \%(y / z)$, where $y$ is the number of interviewees who gave a particular answer and $z$ is the total number of interviewees who responded to that question (Newton et al., 2008). SPSS v. 16.o (SPSS Inc., Chicago, USA) was used for the statistical analyses.

\section{Results}

\section{Interviewees}

Most demographic variables were normally distributed. Interviewees were aged 16-82 $($ mean $=44, \mathrm{n}=200) ; 55 \%$ were male $(111 / 200)$ and $45 \%$ were female $(89 / 200)$. Annual household income was USD 79-4,474 (mean $=1,089$, $\mathrm{n}={ }_{171} ; \mathrm{USD}_{1}=\mathrm{VND}_{19,000}$ at time of writing). Kinh $(91.5 \%, 183 / 200)$ and Khmer $(8.5 \%, 17 / 200)$ were the only two ethnic groups to occur within the sample. The number of people living within a household ranged from one to 11 (mean $=4.6, n=199)$. The highest education level of interviewees varied from no school to university (age when left education was 21), and the mean age at which interviewees left school was 11 years $(n=200)$.

Most interviewees earned their income through farming $(75.5 \%, 151 / 200)$. The majority $(68.5 \%, 137 / 200)$ owned livestock (chickens, ducks, pigs or pythons). Approximately half of the interviewees $(52 \%, 103 / 200)$ regularly went to the market, usually by motorbike or boat but also by bicycle or on foot. The distance to the nearest market was $0.5-60 \mathrm{~km}$ $($ mean $=10 \mathrm{~km}, \mathrm{n}=99)$. 
Only 42\% (84/199) of interviewees raised fish, because of poor water quality, frequent droughts and/or a lack of startup funding. Of those that did, 30\% (25/82) reported problems caused by otters $(50 \%, 16 / 32)$, birds $(25 \%, 8 / 32)$, civets $(15.6 \%, 5 / 32)$, snakes $(6.2 \%, 2 / 32)$ and rodents $(3.1 \%$, $1 / 32)$. The majority of people who experienced predation on their fish stocks took no action $(90.6 \%, 29 / 32)$ but $9.4 \%$ $(3 / 32)$ used snare traps to control animals.

\section{Natural resource use}

Most interviewees (81\%, 162/200) exploited resources, including fish and animals, in the vicinity of their community. Forty-five percent (90/200) of interviewees entered the forest and, of those, $39.5 \%$ (79/200) exploited resources from the forest.

Fishing was carried out by $31.5 \%(63 / 200)$ of interviewees. Participants reported fishing in parties of $1-4$ people (mean$=1.6, \mathrm{n}=45)$. Harvesting figures per trip were $0.5-100 \mathrm{~kg}$ the upper figure occurring when pond owners undertook a single harvest by draining their ponds (mean harvest per trip $=10 \mathrm{~kg}, \mathrm{n}=51$ ). Interviewees said the best season to fish was the rainy season $(68.2 \%, 30 / 57)$, when boat transportation was easiest. Most people harvested fish within their own forest areas $(49.1 \%, 28 / 57)$ but $17.5 \%$ (10/57) harvested within a national park. The remainder $(33.3 \%, 19 / 57)$ harvested in forestry company forest, on community property, or on property of unspecified ownership; otherwise, they chose not to provide information about where they harvested fish (data deficient). Fishing methods included nets $(12.3 \%, 7 / 57)$, hooks $(5.3 \%, 3 / 57)$, traps $(1.8 \%$, $1 / 57)$, electric shock $(7 \%, 4 / 57)$, pond draining $(5.3 \%, 3 / 57)$, or using bare hands $(1.8 \%, 1 / 57)$, but interviewees most commonly reported using a combination of these methods $(66.7 \%, 38 / 57)$. The frequency of fishing ranged from every day to once every 30 days (mean days per month $=22$ ), and $64.9 \%$ (37/57) of interviewees went fishing every day.

Only $5.3 \%(3 / 57)$ harvested fish solely for household consumption and $38.6 \%(22 / 57)$ harvested solely for selling; the majority undertook a combination of both $(56.1 \%$, $32 / 57$ ). The price per $\mathrm{kg}$ was USD $1.05-3.15$ (mean $=1.89$, $\mathrm{n}=48)$. Interviewees most often sold fish to traders $(87 \%$, $47 / 54)$, with $5.6 \%(3 / 54)$ selling to local people and $3.7 \%$ (2/54) selling to a combination of traders and locals. The majority sold fish directly from home $(66.7 \%, 36 / 54)$ followed by selling at the trader's house $(22.2 \%, 12 / 54)$. Fish sold in the dry season fetched higher prices, as did larger fish. Interviewees reported eel as the most expensive fish (USD $5.12 \mathrm{~kg}^{-1}$ ), followed by catfish (USD $2.30 \mathrm{~kg}^{-1}$ ) and snakehead (USD $2.05 \mathrm{~kg}^{-1}$ ).

Hunting or trapping was carried out by $18.5 \%$ (37/200) of interviewees. Species were mainly discussed by taxa because names can vary by location (CARE, 2004a). Hunting parties consisted of $1-5$ people $($ mean $=1.3, \mathrm{n}=21)$. The rainy season was reported as being best for hunting $(63.6 \%, 21 / 33)$ because animals tend to gather in a few areas of elevated, dry land. The frequency of hunting was 1-30 days month ${ }^{-1}$ $($ mean $=20, n=24)$. The majority $(77.4 \%, 24 / 31)$ hunted within the bounds of their own property or forest, although $6.5 \%(2 / 31)$ admitted to hunting within a national park. The remaining $12.9 \%(4 / 37)$ were hunted either in the company forest or in a forest of unspecified ownership.

Interviewees reported hunting birds and snakes most often $(34.5 \%, 19 / 55$ each), followed by turtles (10.9\%, 6/55), pythons $(7.3 \%, 4 / 55)$, eels and pangolins $(3.6 \%, 2 / 55$ each) and water monitors, wild pigs and deer (1.8\%, 1/55 each). Snakes and pythons are categorized separately because interviewees always referred to them as distinct groups. Pythons were often bred in peoples' homes, and water snakes or cobras were trapped and immediately sold or consumed. Hunting methods varied by taxa. Snare traps were most commonly used for catching birds, by placing them on bird trails located in underbrush or rice fields (94.4\%, 17/18), and nets were most often used for catching snakes and pythons $(84.6 \%, 22 / 26)$. Traps were used for hunting turtles, deer and wild pigs, and pangolins were hunted with dogs $(66.6 \%, 2 / 3)$ and traps $(33.3 \%, 1 / 3)$. The numbers of animals caught per hunting effort varied between species (o-10 animals per trip).

Whether animals were trapped for subsistence, for trade or for both varied between taxa (Table 1). Overall, 48.6\% (18/ 37 ) of interviewees hunted only to sell, $37.8 \%$ (14/37) hunted only for household consumption and 13.5\% (5/37) hunted for both consumption and trade. The majority of interviewees sold animals to traders $(66.7 \%, 14 / 21)$ and the remaining $33.3 \%(7 / 21)$ sold to either local people or a combination of local people, traders, and restaurants in $\mathrm{Ca}$ Mau city.

Many interviewees cited 'poor people' as being responsible for violations of forest use. However, we found that variation in wealth did not significantly affect resource use (linear regression: $r^{2}=0.00, F=0.008, \mathrm{df}=1, \mathrm{P}=0.931$ ). We found that location had a significant influence on whether or not local people used natural resources from the national parks or forest and fishery enterprises. People from the forest and fishery enterprises were more likely to exploit the forest than people living around the national parks (total resource use: $39.5 \%, 79 / 200$; national park resource use: $8.3 \%, 10 / 120$; forest and fishery enterprise resource use: $86.2 \%, 69 / 80$; binary logistic regression: $b=2.99, \mathrm{df}=1$, $\mathrm{P}=0.000)$. The frequency of fishery resource use was higher in the forest and fishery enterprises than in the national parks (independent sample $t$-test: $t(\mathrm{df}=53)=$ -3.20, $\mathrm{P}=0.002$ ). Hunting frequency could not be compared because insufficient data were available from the national parks. Demographics did not differ significantly between forest resource users and non-users, except for age. 
TABLE 1 Number of people (and percentage of total respondents) who reported hunting animals; and percentage of taxa eaten, sold, or both eaten and sold. Most animals were discussed only in generic terms with interviewees, who were unable to reliably identify them to species level.

\begin{tabular}{|c|c|c|c|c|}
\hline Species & $\begin{array}{l}\mathrm{n} \text { (\% total } \\
\text { interviewees) }\end{array}$ & $\%$ eaten & $\%$ sold & $\begin{array}{l}\% \text { eaten } \\
\& \text { sold }\end{array}$ \\
\hline Snake & $21(10.5 \%)$ & 19 & 71.4 & 9.5 \\
\hline Water monitor & $1(0.5 \%)$ & 0 & 100 & 0 \\
\hline Python & $3(1.5 \%)$ & 0 & 67 & 33 \\
\hline Turtle & $6(3 \%)$ & 16.7 & 66.7 & 16.7 \\
\hline Pangolin & $2(1 \%)$ & 0 & 100 & 0 \\
\hline Wild pig & $1(0.5 \%)$ & 0 & 100 & 0 \\
\hline Deer & $1(0.5 \%)$ & 0 & 100 & 0 \\
\hline Birds & $18(9 \%)$ & 55.6 & 22.2 & 22.2 \\
\hline
\end{tabular}

Forest users were predominantly middle-aged (83\% were $31-49$ years old; $\left.\chi_{(1,66)}^{2}=4.2576, \mathrm{P}=0.039\right)$. In contrast, only $19 \%$ of non-users were in this age category $\left(\chi_{(1,23)}^{2}=83.96\right.$, $\mathrm{P}=0.000)$, and most non-users were $<30$ years old $(\mathrm{n}=30)$ or $>50(\mathrm{n}=51)$.

\section{Wild meat}

When asked whether they preferred consuming livestock or wild meat, $67 \%(135 / 200)$ of interviewees said they preferred livestock. Men preferred wild meat more than women (wild meat preference: men $67.7 \%$, women $32.3 \%$; $\left.\chi_{(1,65)}^{2}=8.14, \mathrm{P}=0.004\right)$. Consumers who preferred wild meat were predominantly middle-aged $\left(67 \%, \chi_{(1,44)}^{2}=7.458\right.$, $\mathrm{P}=0.0063)$, and $34 \%$ of consumers who preferred livestock were middle-aged $\left(\chi_{(1,46)}^{2}=60.34, \mathrm{P}=0.0000\right)$. The forest and fishery enterprises had the highest percentage of wild meat consumption (53.8\%), and U Minh Thuong had the lowest percentage of residents who preferred wild meat (7.7\%; wild meat preference location: $\chi_{(2,65)}^{2}=22.29$, $\mathrm{P}=0.000$; livestock preference location: $\chi_{(2,135)}^{2}=21.94$, $\mathrm{P}=0.000)$.

The frequency of consumption of wild meat was reported as follows: fish $(25.9 \%, 50 / 193)$, mice $(23.8 \%, 46 / 193)$, snakes $(20.7 \%, 40 / 193)$ and birds $(20.2 \%, 39 / 193)$. However, interviewees indicated that they preferred to consume birds $(16.7 \%, 18 / 108)$, snakes $(16.7 \%, 18 / 108)$ and fish $(15.7 \%, 17 / 108)$, and also species of greater conservation concern such as turtles $(8.3 \%, 9 / 108)$ and pangolins $(6.5 \%$, $7 / 108)$. Snake was perceived to be the most expensive wild meat by $25.9 \%(28 / 108)$ of interviewees, and $13 \%(14 / 108)$ correctly recognized pangolin as the most expensive meat (Fig. 2). We tested the association between wild meat preference and cost as reported by interviewees and found that, in general, there was no association between the two (Spearman rank-order correlation: $\mathrm{n}$ (food preference and cost as reported by interviewees $)=12, \quad r_{s}=-0.044$,

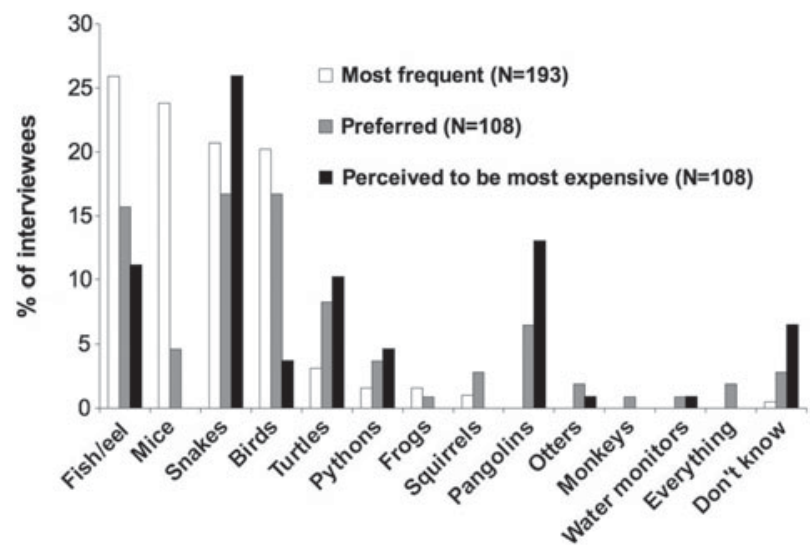

FIG. 2 Interviewees' most frequently consumed wild meat, preferred wild meat, and perception of the most expensive wild meat.

$\mathrm{P}=0.892)$. People who used natural resources from the forest were more likely to prefer wild meat than people who did not harvest forest resources (Mann-Whitney U: mean non-forest users $=1.24 \pm \mathrm{SE} 0.039$, mean forest users $=1.44 \pm \mathrm{SE} 0.056, U=3.84, \mathrm{P}=0.004)$.

\section{Local perceptions}

Interviewees who admitted to using forest resources were questioned regarding their perception of the ease or difficulty of resource harvesting; 70.6\% (36/57) reported that fishing was undemanding and $47.1 \%(16 / 37)$ reported that hunting was undemanding.

Interviewees who harvested fish and animals were also asked whether they perceived species populations to have decreased, increased or remained the same since they began fishing or hunting in the area. For fishing, $82 \%(34 / 41)$ reported that numbers had decreased since they first began fishing in the area, and $73.2 \%(30 / 41)$ attributed this to an increase in the human population and overfishing. Similarly for hunting, $62.2 \%(15 / 24)$ thought animal numbers had 


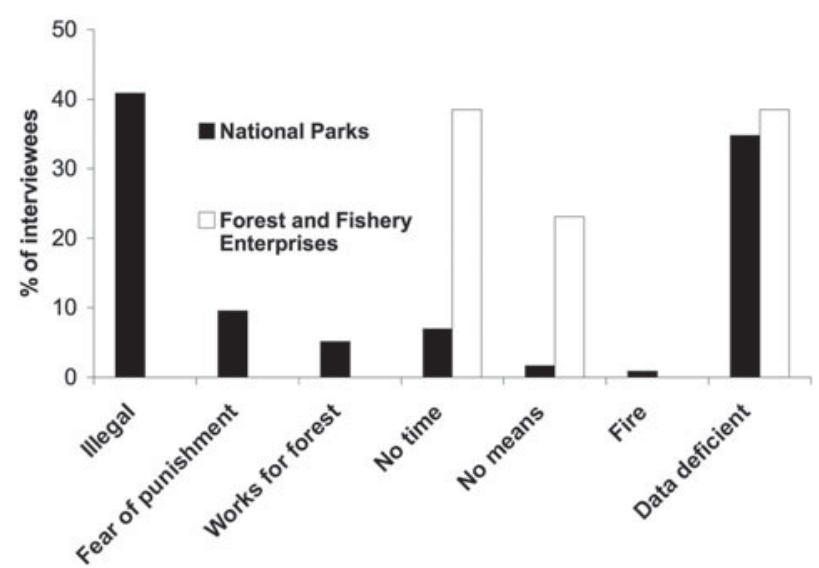

FIG. 3 Reasons interviewees in the national parks $(96 \%, 115 / 120)$ and forest and fishery enterprises $(16 \%, 13 / 80)$ chose not to exploit forest resources. Data deficient interviewees reported not entering the forest but did not cite a reason for choosing not to do so.

decreased since they first began hunting, and $70.8 \%(17 / 24)$ attributed this to pressure from humans. Interviewees who chose not to enter the forest or exploit its resources were questioned about their reasons (Fig. 3). People living within the national parks reported the illegal nature of forest entry and the fear of punishment as the main deterrents $(50.5 \%$, 58/115) whereas people living within the forest and fishery enterprises reported a lack of time $(38.5 \%, 5 / 13)$ and a lack of means $(23.1 \%, 3 / 13)$ as their reasons for not entering the forest.

\section{Discussion}

In $\mathrm{U}$ Minh the presence of law enforcement in areas designated as national parks was found to affect the extent of illegal harvesting activities and the perceived risk of prosecution (Newton et al., 2008). Location significantly influenced the likelihood of interviewees using forest resources, as well as their willingness to report truthfully on their activities in the forest. People living in the buffer zones of $\mathrm{U}$ Minh $\mathrm{Ha}$ and $\mathrm{U}$ Minh Thuong reported partaking in illegal harvesting activities less frequently than people living within the forest and fishery enterprises, where rules are more lenient and patrols less common. This suggests that efforts by the national parks may be regarded as at least partially successful in deterring illegal harvesting and protecting the forest. We established a demographic profile of households in the buffer zones surrounding the two national parks and the forest and fishery enterprises. Further research could focus on the complex drivers that influence an individual's decision whether or not to use forest resources.

This study revealed that the majority of people living within the U Minh landscape prefer to consume livestock, although many still consume wild meat, according to availability and preference. No correlation between food cost and preference was found, indicating that rural Vietnamese may have different motivations for consuming wild meat than urban Vietnamese, who often seek out expensive, rare wild meat as a status symbol (Corlett, 2007; Roberton, 2007; Drury, 2009).

Hunting in $\mathrm{U}$ Minh is characterized by semi-professional and opportunistic hunters (BirdLife, 2008; R. Nuwer, pers. obs.), and opportunistic hunting in U Minh is often paired with fishing. Because of the sensitive nature of some of the interview questions, especially concerning illegal activities in the national parks, the figures reported in this study most likely underestimate the true extent of resource harvesting. This applies particularly to hunting, which is the most explicitly illegal of the activities reported.

Reports by local people of declines and disappearance of species, including birds, mammals, snakes, turtles and other reptiles, indicate that the current hunting pressures may have reached unsustainable levels in some parts of U Minh (Donovan, 2004). People reported that hunting is difficult but fishing is undemanding, which could be explained by the declines in species numbers as well as the more stringent hunting regulations. Fish populations are also in decline, however. An understanding of sustainable exploitation of fish is crucial to the long-term survival of fish populations upon which the people of U Minh depend. Fishermen, including those who fish illegally in the national parks or forest and fishery enterprises, perceive that fishing is an easy activity, which indicates that patrols and the risk of getting caught are inadequate deterrents. Ranger patrols and confiscations could be strengthened, especially during the rainy season when park security is not as stringent. Support from the national parks, government or NGOs in establishing small aquaculture fish ponds, a common practice throughout rural Vietnam, for local households could relieve pressure on wild fish stocks and provide a means of generating income.

Rangers and park staff also have some effect on the national parks. During the dry season some rangers living within the park harvest fish and birds from the core zone for consumption, dispose of their litter on park premises and have been seen feeding and trapping animals, such as monkeys, for entertainment (R. Nuwer, pers. obs.). At U Minh Ha National Park headquarters, staff allowed a group of visitors to consume wild meat acquired outside park premises (c. 20 turtles Malayemys subtrijuga listed under the general forest protection law of Vietnam; R. Nuwer, pers. obs.).

Although their value is difficult to quantify, regulating and provisioning services provided by U Minh's forests, including water filtration, flood control, pollination and forest resources, are vital to the survival of local communities (Buckton et al., 1999). Evidence suggests that current 
rates of exploitation of wildlife are unsustainable and thus should be managed more stringently. Especially in the forest and fishery enterprises, illegal harvesting of natural resources is risky but profitable, and as long as poor law enforcement persists, people will continue to exploit forest resources. Enforcement seems to be deterring the majority of people from entering $\mathrm{U}$ Minh $\mathrm{Ha}$ and U Minh Thuong. However, despite reports that local people living around the national parks perceive the risk of getting caught as outweighing the potential benefits of illegal natural resource harvesting, the numerous trails leading into the parks from the buffer zones as well as anecdotal evidence from interviewees demonstrate that some residents are still exploiting resources within the park boundaries (CARE, 2004; R. Nuwer, pers. obs.). Given the socio-economic issues affecting $\mathrm{U}$ Minh, communities in the region will most likely continue hunting and trading in animals as long as animal prices remain relatively high, equipment is easy to procure and law enforcement is low (BirdLife, 2008). The mean daily income of a household in U Minh is c. USD 3.60 and the mean price for $1 \mathrm{~kg}$ of wild meat is USD 19.75 (as reported by 46 interviewees). The potential for supplementing a low farming income by selling wildlife provides another motivating factor for the persistence of illegal trade in $U$ Minh and throughout Vietnam.

The crucial issue for $\mathrm{U}$ Minh is to understand the level of household dependence on wildlife trade and to identify the factors restricting alternative means of generating income (Roberton, 2007). Interviewees did not identify natural resources as their main source of subsistence or income but they supplemented their income through fishing and hunting. Although illegal harvesting of wildlife products may yield short-term gains, this is insufficient to lift offenders out of poverty (Corlett, 2007). However, some wildlife has a high market value, and most high-value wildlife is sold. Removing this source of income may have a negative effect on the economies of some families. In $U$ Minh there is a need for direct assistance for families, and the lack of government loans and absence of poverty alleviation projects is one of the main drivers of illegal harvesting and trade.

Based on this study we offer several recommendations. Law enforcement should target the main threats of illegal activity through confiscation of equipment, removal of fishing and hunting gear, and punishment for those caught partaking in illegal wildlife hunting or trade. To manage fisheries resources, the National Parks and Forestry Company could develop a maximum sustainable yield quota and management to allow local communities to harvest fisheries resources at sustainable levels (CARE, 2004a). Options for incentive payments to local resource users on condition that they comply with wildlife harvest regulations could also be explored. Finally, we recommend workshops to inform and change ranger behaviour concerning trapping of animals and litter disposal, and a strict ban on serving wild meat within national parks.

\section{Acknowledgements}

We are grateful to the Small Carnivore and Pangolin Conservation Program and the Wildlife Conservation Society, particularly Daniel Willcox, Scott Roberton and Tran Quang Phuong, for logistical support and guidance. For translation and assistance in the field we thank Lam Dinh Uy. For technical and statistical advice we thank Kelly Edmunds and Andres Gomez. We also thank the National Geographic Society, the Thrigby Hall Conservation Gardens, the Whitley Wildlife Conservation Trust and the Sir Philip Reckitt Educational Trust for making this study possible through their generous support. The University of East Anglia's School of Biological Sciences provided ethical review for this study.

\section{References}

Bennett, E.L., Milner-Gulland, E.J., Bakarr, M., Eves, H.E., Robinson, J.G. \& Wilkie, D.S. (2002) Hunting the world's wildlife to extinction. Oryx, 36, 328-329.

BirdLife (2008) The Illegal Wildlife Trade Networks Around Bac Huong Hoa Nature Reserve, Quang Tri Province, Vietnam. BirdLife International Vietnam Programme, Hanoi, Vietnam.

Buckton, S.T., Nguyen, C., NGuyen, D.T. \& Ha, Q.Q. (1999) Conservation of Key Wetland Sites in the Mekong Delta. BirdLife International Vietnam Programme Conservation Report No. 12. BirdLife International Vietnam Programme, Hanoi, Vietnam.

Bull, R., Nhuan, V.N. \& Roberton, S. (2008) Tapping Local Knowledge: Hunting Methods and Potential Habitat Associations for Carnivores and Pangolins of the U Minh Peat Swamp Forests, South Vietnam. CPCP, Cuc Phuong, Vietnam.

CARE (2004a) CARE Biodiversity Survey, U Minh Thuong National Park. Agricultural Publishing House, Ho Chi Minh City, Vietnam.

CARE (2004b) U Minh Thuong National Park. Agricultural

Publishing House, Ho Chi Minh City, Vietnam.

CARE (2004c) Voi Doi Nature Reserve. Agricultural Publishing House, Ho Chi Minh City, Vietnam.

Corlett, R. (2007) The impact of hunting on the mammalian fauna of tropical Asian forests. Biotropica, 39, 292-303.

Donovan, D. (2004) Cultural underpinnings of the wildlife trade in Southeast Asia. In Wildlife in Asia: Cultural Perspectives (ed. J. Knight), pp. 88-111. Routledge Curzon, London, UK.

DRURY, R. (2009) Reducing urban demand for wild animals in Vietnam: examining the potential of wildlife farming as a conservation tool. Conservation Letters, 2, 263-270.

IUCN (2012) Threatened species in each country (totals by taxonomic group). Http://www.iucnredlist.org/documents/summarystatistics/ 2012_2_RL_Stats_Table_5.pdf [accessed 1 June 2013].

Milner-Gulland, E.J. \& Rowcliffe, J.M. (2007) Conservation and Sustainable Use: A Handbook of Techniques. Oxford University Press, New York, USA.

Newton, P., Roberton, S. \& Bell, D. (2008) Pangolins in peril: using local hunters' knowledge to conserve elusive species in Vietnam.

Endangered Species Research, 6, 41-53. 
NGUyen, S.V. (2008) Wildlife trading in Vietnam: situation, causes, and solutions. Journal of Environment and Development, 17, 145-165. RedFord, K. (1992) The empty forest. BioScience, 42, 412-422.

ROBERTON, S. (2007) The status and conservation of small carnivores in Vietnam. PhD thesis. University of East Anglia, Norwich, UK.

Torell, M., Salamanca, A. \& Ratner, B. (eds) (2003) Wetlands Management in Vietnam: Issues and Perspectives. World Fish Center, Penang, Malaysia.

TRAFFIC (2008) What's Driving the Wildlife Trade? A Review of Expert Opinion on Economic and Social Drivers of the Wildlife Trade and Trade Control Efforts in Cambodia, Indonesia, Laos, and Vietnam. World Bank, Washington, DC, USA.

WCS (2009) Household Living Standards of Commercial Hunters and Wholesale Wildlife Traders in Vietnam. Wildlife Conservation Society, Hanoi, Vietnam.
World B ANK (2005) Vietnam Environment Monitor 2005: Biodiversity. World Bank, Washington, DC, USA.

\section{Biographical sketches}

Rachel Nuwer completed a Master's degree in ecology at the University of East Anglia in 2010. She currently lives in New York and works as a freelance science journalist. She writes about conservation, the environment and wildlife trade for The New York Times, Scientific American and Audubon Magazine, among others. DiANA BELL is a conservation biologist with over 30 years' experience of species and habitat recovery on several continents. She also works on emerging infectious diseases and wildlife trade. 